\title{
COMMUNITY EMPOWERMENT IN REDUCING ENVIRONMENTAL POLLUTION THROUGH PROCESSING OF TERASI (DRIED SHRIMP PASTE) WASTE INTO ORGANIC LIQUID FERTILIZER
}

\author{
Awatiful Azza', Diyan Indriyani², Ika Priantari ${ }^{3}$ \\ $1{ }^{2}$ Faculty of Health science University of Muhammadiyah Jember \\ ${ }^{3}$ Biology Major University of Muhammadiyah Jember \\ Corresponding E-mail : awatiful.azza@unmuhjember.ac.id, diyanindriyani@unmuhjember.ac.id, \\ ichapriantari.83@gmail.com
}

\begin{abstract}
BACKGROUND : Community empowerment is a systematic action and involves various formal and informal organizational components in the community. Community empowerment must be based on the assumption, that the community is the owner of the authority that determines the needs and strategies to achieve those needs.

SUBJECT AND METHODE : The KKN-PPM (Kuliah Kerja Nyata-Pembelajaran Pemberdayaan Masyarakat) activity involves the entire community to reduce pollution from dried shrimp paste by processing it into fertilizer which can improve the welfare of the Puger Kulon community. The manufacturing process of liquid organic fertilizer using the method of fermentation technology by bio activators/decomposer agents Effective Microorganism 4 (EM4) which aims to accelerate the formation of liquid fertilizer from dried shrimp paste waste.

RESULTS : Providing alternative solutions to reduce pollution of dried shrimp paste by processing it into fertilizer that can improve the welfare of the Puger Kulon community.

CONCLUSION : This program is able to reduce the impact of environmental pollution by processing dried shrimp paste waste into an organic liquid fertilizer that both can be produced by the community itself and used to support natural greening program.
\end{abstract}

Keywords: dried shrimp paste waste, organic liquid fertilizer.

\section{INTRODUCTION}

Community empowerment is a systematic action and involves various formal and informal organizational components in the community (Timur, 2014). The implementation of community empowerment requires programs and activities that can directly involve the community's participation (Perkins \& Zimmerman, 1995).

Conceptually, community empowerment must be based on the assumption, that the community is the owner of the authority that determines the needs and strategies to achieve those needs, so that all processes including planning, implementation, and supervision have to be carried out by the community themselves so that the continuity of this empowerment can be perceived by the community(Perkins \& Zimmerman, 1995).

Indonesia as an archipelago has a lot of fishery product processing industry which will produce tons of waste. Utilization of waste in the fisheries and marine sector not only provides added value to the community but also can overcome the problem of environmental pollution that is caused, 
especially the issue of odor produced and poor environmental aesthetics(Tanaka, Taku, Lin, \& Kobayashi, 2005).

The district of Jember which is part of the southern coast of Java also has the potential of the fishery and marine product processing industry, namely "Terasi Puger". Terasi (dried shrimp paste) is one of the spices that come from the fermentation of fish or shrimp, but the problem faced by the industry is waste that pollutes the air and the environment(Anaerobic Fermentation of Food Waste in Phuket Province using Yeast Jutarat Suwannarat A Thesis Submitted in Partial Fulfillment of the Requirements for the Degree of Master of Science in Technology and Environmental Management Prince of Songkla Universit, 2014).

Reducing environmental pollution requires joint efforts through community empowerment in tackling dried shrimp paste waste. One of the empowerment methods that can be done to manage dried shrimp paste waste is to process waste into organic liquid fertilizer. Fertilizer is a material used to add nutrients to the soil and provide the needs of plants so that it can grow optimally(Ma et al., 2018).

Team of KKN-PPM (Kuliah Kerja Nyata-Pembelajaran Pemberdayaan Masyarakat) University of Muhammadiyah Jember together with the community tried to provide alternative solutions to reduce pollution of dried shrimp paste by processing it into fertilizer that can improve the welfare of the Puger Kulon community.

The objective of this activity is to overview of the impact of waste on environmental health, as well as solutions to overcome dried shrimp paste waste pollution through the manufacture of organic liquid fertilizer.

\section{LITERATURE REVIEW}

\section{a. Organic liquid fertilizer from dried shrimp paste waste}

Terasi (dried shrimp paste) is one of the very popular food seasonings in Indonesia. The basic ingredients of dried shrimp paste are fish and shrimp(Anaerobic Fermentation of Food Waste in Phuket Province using Yeast Jutarat Suwannarat A Thesis Submitted in Partial Fulfillment of the Requirements for the Degree of Master of Science in Technology and Environmental Management Prince of Songkla Universit, 2014). The final product in dried shrimp paste industry will produce waste that risk of polluting the environment and one of the waste is shrimp shells(Sutapa, 2018). Shrimp shells waste contains main constituents consisting of protein, calcium carbonate, chitin, phikmen, dust, etc. In addition, the waste of dry head shrimp contains high protein and high levels of minerals, especially $\mathrm{Cu}, \mathrm{P}, \mathrm{Mn}$ and $\mathrm{Zn}$ which are important nutrients for plant growth. Shrimp shells waste consists of three main components including protein $(25-44 \%)$, calcium carbonate (45-50\%), and chitin (15-20\%). Chitin content in shrimp shell waste is around $20 \%-50 \%$ dry weight. One of the functions of chitin in agriculture is to increase nitrogen fixation, where it affects plant growth. The dried shrimp paste waste treatment can help the community in reducing environmental pollution and the results can support the family economy(Hapsari \& Welasih, 2015).

Organic liquid fertilizer is a one of form processed shrimp waste into an economically valuable material and can reduce environmental pollution. The advantages of organic fertilizer are (1) improves chemical properties of the soil, (2) improves physical properties of the soil, (3) increase soil microorganisms, (4) food source for plants, (5) environmentally friendly, (6) organic fertilizers are cheaper, and (7) increase production quality(Febrianna, Prijono, \& Kusumarini, 2018). 
The addition of banana stems aims to create the composition of organic liquid fertilizer from shrimp waste complete nutritional content for plants. The content in banana stems according to various studies including dry matter $87.7 \%$, dust $25.12 \%$, crude fat $14.23 \%$, crude fiber $29.40 \%$, crude protein $3 \%$ including amino acids, amine nitrate, glycosides, containing $\mathrm{N}$, glycolipids, $\mathrm{B}$ vitamins, nucleic acids, including carbohydrates, sugars, and starches(Febrianna et al., 2018).

\section{b. The manufacturing process of organic liquid fertilizer}

Plants in the process of growth and development require two types of nutrients, macro, and micronutrients in the soil. However, sometimes these two nutrients are not available in sufficient quantities. Both nutrients needed by these plants can be fulfilled through proper and balanced fertilization. Excess and lack of nutrients both micro and macronutrients can cause plant growth less optimal. Macro and microelements that must be available for plants are only N, P, and $\mathrm{K}$ elements which needed in greater quantities than other elements. Therefore, these three elements are often called the main (primary) macronutrients(Astuti \& Mahatmanti, 2018). One type of fertilizer that can provide the needs of nutrients $N, P$, and $K$ and also environmental friendly is organic liquid fertilizer, which is obtained from the process of composting (decomposition) of organic materials in the composter container.

The manufacturing process of liquid organic fertilizer using the method of fermentation technology by bio activators/decomposer agents Effective Microorganism 4 (EM4) which aims to accelerate the formation of liquid fertilizer from dried shrimp paste waste from 3 months to 7-14 days. EM4 contains fermented and synthetic microorganisms consisting of lactic acid bacteria (Lactobacillus sp.), Photosynthetic bacteria (Rhodopseudomonas sp.), Actinomycetes sp., Streptomycetes $s p$. and yeast.

The fermentation process of organic liquid fertilizer is carried out in an anaerobic condition. The materials and tools needed for this shrimp waste processing include:

A. Ingredients

- Shrimp waste (shell or head)

- Banana stems

- EM4

- Glucose solution

- EM4

- Rice washing water

- Coconut water

B. Tools

- Container with cover

- Measuring glass

- Stirrer or wooden stick

C. Process

- Dissolve $200 \mathrm{cc}$ bio activators such as EM4 as microbes in sufficient water (5 liters of coconut water and 2 liters of rice washing water)

- Put shrimp/fish/shrimp paste waste into buckets or container

- Add ingredients that we have chopped and mix it gently into buckets or container

- Add all the other solid ingredients and mix well

- Pour a bio activator solution that has been prepared before and add shrimp paste to further speed up the process of decomposing organic liquid fertilizer if necessary 
- Add rice washing water, fish marinade and liquid ingredients, other coconut water into a bucket, stir until evenly distributed

- Add enough water, the ratio of water is 35 percent liquid and 65 percent solid. Stir gently using a wooden stick

- Let stand for approximately 10 days, after 10 days see whether the liquid organic fertilizer is ripe if it is not yet ripe close again tightly until the odor from the fertilizer resembles the scent of fermented cassava

The advantage of organic liquid fertilizer is rich in a variety of minerals, and essential substances needed by the soil and plants, as well as plant growth hormones. In addition, organic liquid fertilizer can also stimulate plant growth and can effectively increase the cation exchange capacity of the soil, when compared to chemical fertilizers(Ma et al., 2018). Cation exchange capacity is the ability of the soil to increase interactions between ions in the soil so that it is able to provide various elements needed by plants. The organic material used for organic liquid fertilizer will be able to reduce the number of nutrients that are bound to soil minerals so that more nutrients are available to plants(Tanaka et al., 2005).

\section{a. Conclusion}

\section{CONCLUSION AND SUGGESTION}

The community empowerment program through the KKN-PPM program is able to reduce the impact of environmental pollution by processing dried shrimp paste waste into an organic liquid fertilizer that can be produced by the community and for natural greening program.

\section{b. Suggestion}

The basic ingredients of making organic liquid fertilizer must be adapted to the purpose of fertilizing plants for optimal use.

\section{REFERENCE}

Anaerobic Fermentation of Food Waste in Phuket Province using Yeast Jutarat Suwannarat A Thesis Submitted in Partial Fulfillment of the Requirements for the Degree of Master of Science in Technology and Environmental Management Prince of Songkla Universit. (2014). (1).

Astuti, W., \& Mahatmanti, W. (2018). Pembuatan Pupuk Fermentasi Cair Berbasis Limbah Vinasse. Rekayasa, 15(1), 55-58.

Febrianna, M., Prijono, S., \& Kusumarini, N. (2018). pemanfaatan pupuk organik cair untuk MENINGKATKAN SERAPAN NITROGEN SERTA PERTUMBUHAN DAN PRODUKSI SAWI ( Brassica juncea $L$.) PADA TANAH BERPASIR The use of Liquid Organic Fertilizer to Increase Nitrogen Uptake and Growth and Yield of Mustard ( Brassica j. Tanah Dan Sumberdaya Lahan, 5(2), 1009-1018.

Hapsari, N., \& Welasih, T. (2015). Pemanfaatan limbah ikan menjadi pupuk organik. 1(1), 1-6.

Ma, H., Peng, C., Jia, Y., Wang, Q., Tu, M., \& Gao, M. (2018). Effect of fermentation stillage of food waste on bioelectricity production and microbial community structure in microbial fuel cells. 
Royal Society Open Science, 5(9). https://doi.org/10.1098/rsos.180457

Perkins, D. D., \& Zimmerman, M. A. (1995). Empowerment theory, research, and application. American Journal of Community Psychology, 23(5), 569-579. https://doi.org/10.1007/BF02506982

Tanaka, S., Taku, K., Lin, Y., \& Kobayashi, T. (2005). Environmental Conservation by Fermentation of Biomass in Asia. Environmental Research, 5517-5517. 